TITLE:

\title{
Stacking Fault Probabilities in Copper-Aluminum Martensite Transformed in Thin Foils( Abstract_要旨)
}

\section{AUTHOR(S):}

Kajiwara, Setsuo

\section{CITATION:}

Kajiwara, Setsuo. Stacking Fault Probabilities in Copper-Aluminum Martensite Transformed in Thin Foils. 京都大学, 1967, 理学博士

ISSUE DATE:

1967-03-23

URL:

http://hdl.handle.net/2433/212184

RIGHT: 


\section{【69】}

氏 名

学位の種 類

学位記 番号

学位授与の日付

学位授与の要件

学位諭交題目

論文調查委員

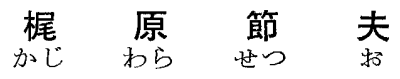

理学 博士

論 理 博 第 183 号

昭 和 42 年 3 月 23 日

学位規則第 5 条第 2 項該当

\section{Stacking Fault Probabilities in Copper-Aluminum} Martensite Transformed in Thin Foils

（薄膜中で相変態した銅一アルミニウム合金のマルテンサイ 卜におりる積層欠陷の頻度）

(主 查)

教授田中憲三教授松原武生教授長谷田泰一郎

教 授 浅井健次郎

\section{論文内容の要旨}

本論文は銅一アルミニウム合金の $\beta^{\prime}$ マルテンサイトについて，それが多数の積層欠楩を含むむので， その欠陥出現の頻度は各マルテンサイト晶ごとに異なっているととを見出し, その原因として変態の際に 周囲から受ける拘束力が各結晶ごとに異なっていると考元, 拘束力の小さい薄膜の場合には大きい試料と は異なった频度で積層火陷が現われるとの推察のもとに，その点荙明らかにする目的で行なった研究であ る。

試料としては $\mathrm{Cu}-\mathrm{A} 1$ 合金（A1 11.9 重量％）の薄膜を用い，高温から急冷してマルテンサイト変態さ せたものを電子顕微鏡の制限視野回折法で調べた。得られた電子回折像に㧍ける回折斑点の移動を測定 し，その移動の量から積層欠陥出現の頻度を求めた。

故マルテンサイトの結晶は斜方格子で, 面心立方格子に 3 層抢きに規則的に積層欠陥が入った場合に相 当する。乙の結晶の逆格子は基本的には $C^{*}$ 軸の力向に並んだ 3 種の逆格子点の列加らなり立っている。 この結晶に不規則に積層欠陷が入るとこれらの逆格子点は移動したり粗大になったりする。

観測された電子回折斑点の移動の程度は一定でなく，上記の結晶構造に近いすのから，次第に移動量が 大きくなり，ついには六方稠密格子型にいたるまでの各段階のものが見出された。このような回折斑点の 移動を不整格子に対する杮木と小村の回折理論を適用して解折した。この理論によると上述のような結晶 構造に積層欠陥が入った場合その積層不整を記述するには一般に 4 つのパラメータが必要であるが, 本実 験の場合は回折斑点の移動の仕方が特殊であるため1つのパラメータ $\beta$ のみで記述することができた。 $\beta$ の意味は，その值が０の場合は積層欠陥を含まない完全な基本構造を表わし， $\beta$ の值が堌加するに従って 積層欠陷の步度が増し，次第に六方䅕密格子型に近づくようなもので， $\beta=1$ は六方䅕密格子型の完全結 晶の状態を表わす。

$\beta$ の值と回折斑点の移動量（計算值）との関係を表わすグラフをつくり，乙れを用いて移動量の観湘值 に対応する $\beta$ の值在求めた。その結果， $\beta=0.06 \sim 1.0$ の広範囲にわたっていた。またてれら $\beta$ の值に対す 
る回折斑点の強度分布の計算值と観測值の一致は極めて良好であった。

この結果で注目すべきことは，薄膜の場合，大きい試料には見られなかった $\beta$ 值の大きいものが観測 されたととである。乙のととは, 薄膜試料の変態のときはマルテンサイトは六方稠密格子型に近づく傾向 が強いととを示している。またとのととを確かめるため一つのマルテンサイト晶の薄い部分と厚い部分の 電子回折像をとり， $\beta$ の值を求めた結果, 試料の膜厚が減少するほど $\beta$ の值が増加するととが时らかとな り，上記の事柄を確認した。

この事実から Cu-A1 の $\beta^{\prime}$ マルテンサイトは, 試料が大きい場合は変態の際周团から受ける拘束が大 きいためより安定な構造と考えられる六方稠密格子型にはなり得ず斜方格子となっているが, 薄膜試料の 場合は拘束が小さいため安定な格子型に近づくというととが推論されている。

\section{論 文 審 査 の 結 果 の 要旨}

拡散を伴う相変態に対してこれを伴わない相変態, すなわちマルテンサイト変態が存在するということ は，合金については古くから知られている。との変態は，一般に高温相の状態から急冷するととによって おこるあのであるが，変態に伴ってかなりの量のひずみがマルテンサイト晶中に生ずると考えられる。近 年, 電子顕微鏡による直接観察によっててれらマルテンサイト晶の中に主として微細な双晶かまたは積層 欠宿が多数存在しているということが明らかにされた。

申請者は多年にわたって銅一アルミニウム合金の $\beta^{\prime}$ マルテンサイトの研究を続けているが，その中に は非常に多くの積層火陥が含まれていて，しかもその頻度は各マルテンサイト晶ごとに異なっていること を見出した。このととは, 変態の際結晶が周囲から受ける拘束が各マルテンサイト晶ごとに異なるととに よると考えた。またての拘束の大小は試料の大きさに関係あるものとみて大きい試料の場合（参考論文 5 ）と薄膜試料の場合（主論文）について積層欠陥の出現の頻度を比較した。

この頻度は電子回折像の回折斑点の移動の大きさから柿木と小村の回折理論を適用して求められた。観 測の結果は始めの予想の如く試料の膜厚が小さくなるほど積層欠階の頻度が増し, 欠陥を含まない基本的 な構造（斜方晶）から次第に安定な六方稠密格子型の構造に近づくことを見出した。

この研究は特殊な 1 種類の合金について行われたものであるが，一般のマルテンサイト変態の場合の機 構の考察に十分役立つものであり, 観測の方法とその結果の処理についても妥当なものと考えられる。し たがってとの分野の研究に対し貢献するととろが大であるといえる。

よって, 本論文は理学博士の学位論文として洒值があるものと認める。 